\title{
EFFECT ON ISOFLURANE ANAESTHESIA AND SURGERY ON THYROID FUNCTION IN MAN
}

\author{
T. Oyama, ${ }^{\circ}$ P. Latto, D.A. Holaday, and H. Chang
}

THE EFFECTS of various anaesthetic agents on the activity of the thyroid gland have been reported.1-5 However, no study has been published on the effects of isoflurane anaesthesia on thyroid function. The present study was undertaken to investigate the effects of isoflurane anaesthesia and surgery on serum thyroxine concentrations, in the belief that exploration of the role of thyroid activity as an endocrine response to acute stress would be helpful in the management of patients with abnormal thyroid function.

\section{METHods}

Nine male patients, ranging in age from 24 to 56 years, were the subjects of the study (Table I). No patients were included who had hepatic, renal, endocrinologic or cardiovascular disease. They were all premedicated with $100 \mathrm{mg}$ of pentobarbitone and $0.5 \mathrm{mg}$ of atropine intramuscularly one hour before anaesthesia.

Anaesthesia was induced with intravenous thiopentone $3-5 \mathrm{ml} / \mathrm{kg}$, and tracheal intubation was performed after administration of $100 \mathrm{mg}$ of succinylcholine. Liquid isoflurane was injected from a $20 \mathrm{ml}$ Hamilton syringe into the circle system, powered by a Harvard Mark 2 dose-regulated anaesthesia pump which was controlled by a Data Trak (Model 5500 ). The infusion was programmed to provide an alveolar isoflurane concentration equivalent to its MAC (1.27 per cent). Oxygen was added to the circuit at a rate of approximately $250 \mathrm{ml} / \mathrm{min}$ to match metabolic consumption. The patient's ventilation was controlled by an OHIO Ventilator $(300 \mathrm{D} / \mathrm{O})$. The patient's $\mathrm{Pa}_{\mathrm{CO}_{2}}$ remained within the normal range determined by periodic blood gas analysis. Adequate muscle relaxation was obtained with d-tubocurarine. Four arterial samples of 2 to $3 \mathrm{ml}$ were taken during anaesthesia and analyzed by gas chromatography for isoflurane concentrations. One $\mathrm{ml}$ of blood was equilibrated with $1 \mathrm{ml}$ of hexane; $0.3 \mu \mathrm{l}$ aliquots of hexane were then injected into a Hewlett-Packard high efficiency gas chromatograph (Model 7610A) fitted with a hydrogen flame. Mean arterial isoflurane concentrations were 13.0 (SEM [standard error of the mean] $=1.1$ ) and 10.8 $(\mathrm{SEM}=1.2) \mathrm{mg} / 100 \mathrm{ml}$ at 30 minutes after the induction and one hour after the start of surgery, respectively.

Thyroxine $\left(T_{4}\right)$ concentration and triiodothyronine uptake $\left(T_{3} U\right)$ in venous

From the Department of Anesthesiology, University of Miami School of Medicine, Miami, Florida.

-Present address: Prof. T. Oyama, M.D., Department of Anaesthesia, Hirosaki University School of Medicine, Hirosaki, Aomori-ken, Japan. 
TABLE I

Patients Studied and Operations Performed

\begin{tabular}{ccccc}
\hline \hline $\begin{array}{c}\text { Patient } \\
\text { No. }\end{array}$ & Age & $\begin{array}{c}\text { Weight } \\
(\mathrm{kg})\end{array}$ & \multicolumn{1}{c}{ Surgical procedure } & $\begin{array}{c}\text { Duration of } \\
\text { anaesthesia (min) }\end{array}$ \\
\hline 1 & 28 & 65 & Inguinal herniorrhaphy & 100 \\
2 & 52 & 95 & Inguinal herniorrhaphy & 101 \\
3 & 24 & 72 & Inguinal herniorrhaphy & 92 \\
4 & 24 & 64 & Inguinal herniorrhaphy & 77 \\
5 & 56 & 66 & Lumbar laminectomy & 156 \\
6 & 39 & 99 & Lumbar laminectomy & 209 \\
7 & 42 & 74 & Osteotomy fibula & 165 \\
8 & 46 & 79 & Ventral incisional herniorrhaphy & 103 \\
9 & 56 & 85 & Ventral hernia repair & 160 \\
\hline
\end{tabular}

serum were determined by column chromatography utilizing ${ }^{125} \mathrm{I}$-labeled $\mathrm{T}_{4}$ and $T_{3}$ through Sephadex 25.6 Free thyroxine index $\left(T_{7}\right)$ was calculated from $T_{3} U$ and $\mathrm{T}_{4}$ according to the following formula, multiplying by a correction factor. ${ }^{7,8}$

$$
T_{7}=\frac{T_{3} U(\%)}{100} \times T_{4}(m c g \%)
$$

On the day of anaesthesia, five $\mathrm{ml}$ of venous blood was drawn at intervals: (1) five minutes before induction of anaesthesia; (2) 15 and 30 minutes after the induction, but before the start of surgery; (3) one hour after the start of surgery; and $(4)$ in the recovery room after the patient had recovered adequately from anaesthesia. Statistical analysis was made by a paired Student's $t$ test.

\section{Results}

The mean control plasma thyroxine $\left(\mathrm{T}_{4}\right)$ concentration was $4.3(\mathrm{SEM}=0.3$ ) $\mathrm{mcg} / 100 \mathrm{ml}$. It increased by 20 per cent, to $5.2 \mathrm{mcg} / 100 \mathrm{ml}$, at 30 minutes after induction, but the change was not statistically significant. Blood $\mathrm{T}_{4}$ concentration increased significantly $(\mathrm{p}<0.005)$ to $5.9 \mathrm{mcg} / 100 \mathrm{ml}$ (37 per cent increase from control) one hour after the start of surgery, and remained elevated ( $p<0.02$, 23 per cent increase over control) in the recovery room period.

The mean control plasma triiodothyronine uptake $\left(T_{3} U\right)$ value was 50.8 per cent $(\mathrm{SEM}=2,1)$. It became elevated significantly by 21 per cent 15 minutes after induction and 20 per cent at 30 minutes; by 18 per cent one hour after the start of surgery and 12 per cent in the recovery room (Table II). Plasma free thyroxine index $\left(T_{7}\right)$ rose significantly $(p<0.005)$ from a control value of 4.2 ( $\mathrm{SEM}=0.4$ ) by $21,42,50$ and 69 per cent at the intervals indicated (Table II).

\section{Discussion}

The measurement of $T_{4}$ in our study estimates total blood thyroxine, both protein-bound and free. The major part of thyroxine $\left(\mathrm{T}_{4}\right)$ secreted by the thyroid gland is bound to the $T_{4}$ binding globulin (TBG) and a small portion circulates as free thyroxine. Thus, it offers a measure of the output or activity of the thyroid gland. In general, blood $\mathrm{T}_{4}$ values are elevated in hyperthyroidism and are low- 
TABLE II

Effect of Isoflurane Anaesthesia and Surgery on Blood $T_{3}, T_{4}$ AND FREE THYROXINE INDEX

\begin{tabular}{|c|c|c|c|c|}
\hline Control & $\begin{array}{l}15 \text { minutes } \\
\text { after induction }\end{array}$ & $\begin{array}{l}30 \text { minutes } \\
\text { after induction }\end{array}$ & $\begin{array}{l}\text { One hour } \\
\text { after incision }\end{array}$ & Recovery room \\
\hline $\begin{array}{l}\mathrm{T}_{3}(\% \text { retention }) \\
50.8 \pm 2.1\end{array}$ & $\begin{array}{l}57.3 \pm 2.8 \\
(\mathrm{p}<0.02)\end{array}$ & $\begin{array}{c}59.3 \pm 2.9 \\
(\mathrm{p}<0.005) \\
\uparrow(18.3 \%)\end{array}$ & $\begin{array}{c}61.0 \pm 2.8 \\
(\mathrm{p}<0.005) \\
\uparrow(20 \%)\end{array}$ & $\begin{array}{c}57.2 \pm 2.6 \\
(\mathrm{p}<0.01) \\
\uparrow(12.5 \%)\end{array}$ \\
\hline $\begin{array}{l}\mathrm{T}_{4}(\mathrm{mcg} / 100 \mathrm{ml}) \\
4.3 \pm 0.3\end{array}$ & $\begin{array}{l}4.6 \pm 0.3 \\
(\mathrm{NS})^{*}\end{array}$ & $\begin{array}{c}5.2 \pm 0.1 \\
(\mathrm{p}<0.05) \\
\uparrow(20 \%)\end{array}$ & $\begin{array}{c}5.9 \pm 0.3 \\
(\mathrm{p} \underset{<0.05)}{ }<(37 \%)\end{array}$ & $\begin{array}{c}5.3 \pm 0.4 \\
(p<0.02) \\
\uparrow(23 \%)\end{array}$ \\
\hline $\begin{array}{l}\text { Free thyroxine index } \\
\quad 4.2 \pm 0.4\end{array}$ & $\begin{array}{c}5.1 \pm 0.4 \\
(\mathrm{p}<0.005)\end{array}$ & $\begin{array}{c}6.0 \pm 0.3 \\
(\mathrm{p}<0.0005) \\
\uparrow(62.8 \%)\end{array}$ & 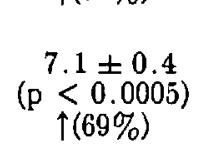 & $\begin{array}{c}6.3 \pm 0.4 \\
(\mathrm{p}<0.0025) \\
\uparrow(50 \%)\end{array}$ \\
\hline
\end{tabular}

*NS = not significant.

ered in hypothyroidism. Blood $T_{4}$ concentrations tended to increase during isoflurane anaesthesia alone, and further elevation of blood $\mathrm{T}_{4}$ was measured during surgery. Although blood levels of $T_{4}$ remained within the range of normal, they showed the same tendency to become elevated as has been reported to occur during diethyl ether ${ }^{1,2}$ and halothane anaesthesia, ${ }^{3,5}$ but different from that during thiopentone-nitrous oxide anaesthesia in which the blood $\mathrm{T}_{4}$ level decreased. ${ }^{1}$

The $T_{3} U$ correlates with the ratio of $T_{4}$ to $T B G$, which indirectly reflects the changes in blood $\mathrm{T}_{4}$ levels. ${ }^{6.7}$ In hyperthyroidism, the overactive gland secretes excessive amounts of $T_{4}$, which more fully saturate the primary binding sites of the TBG. When isotopic triiodothyronine is added as a $T_{3} U$ test, less radioactive $\mathrm{T}_{3}$ binds to the TBG and more binds to the secondary binding sites in the resin sponge. In hypothyroidism, the gland secretes less $\mathrm{T}_{4}$ than normal and the primary binding sites on the TBG are less fully saturated. The added labeled $\mathrm{T}_{3}$ then distributes itself so that more is bound to primary binding sites of the TBG and less is found on the resin sponge. The $T_{3} U$ is thus increased in hyperthyroidism and is decreased in hypothyroidism. Although the magnitude of the changes of $T_{3} \mathrm{U}$ during isoflurane anaesthesia alone and surgery remained within normal range of change ( 43 to 60 per cent), when taken together they increased significantly during the procedure (Table II).

Free thyroxine index $\left(T_{7}\right)$ is related to the patient's circulating free $T_{4} \cdot{ }^{6,7}$ The relative change in the concentration of free thyroid hormones, as reflected in the $T_{7}$, was greater than the change in total thyroxine. This would imply that the primary alteration was in the concentrations of free thyroid hormones in the blood rather than in that of thyroid-binding proteins. The observed changes suggest that isoflurane anaesthesia and surgery increased circulating thyroxine.

Since isoflurane anaesthesia increased circulating thyroxine in response to surgery, from a theoretical point of view isoflurane anaesthesia, like diethyl ether and halothane, appears to be disadvantageous to patients with hyperthyroidism. In contrast, we have found that thiopentone and spinal anaesthesia decrease or have little effect on blood levels of thyroid hormones. ${ }^{1,4}$ Accordingly, the latter 
anaesthetics may be preferable for patients with hyperthyroidism. Further studies are indicated to evaluate the effect of isoflurane anaesthesia on hyperthyroidism.

\section{SUMMARY}

The effect of isoflurane (Forane ${ }^{*}$ ) anaesthesia and surgery on thyroid function was investigated in nine male patients. Isoflurane anaesthesia alone for $30 \mathrm{~min}$ utes prior to the start of surgery increased plasma triiodothyronine uptake $\left(\mathrm{T}_{3} \mathrm{U}\right)$ and thyroxine $\left(\mathrm{T}_{4}\right)$ level by 18 and 20 per cent, respectively. Free thyroxine index (FTI) values in blood increased by 62 per cent during the same period. One hour of surgical procedure further elevated these parameters. Our data indicate that isoflurane anaesthesia and surgery increase circulating thyroxine in man.

\section{RÉSUMÉ}

L'effet de l'anesthésie à l'isoflurane (Forane) et de la chirurgie sur la fonction thyroïdienne a fait l'objet d'une étude chez neuf patients. L'anesthésie à l'isoflurane seul pendant $30 \mathrm{~min}$ avant le début de la chirurgie a provoqué une augmentation de la captation de la triiodothyronine $\left(\mathrm{T}_{33} \mathrm{U}\right)$ et de la thyroxine $\left(\mathrm{T}_{4}\right)$ de 18 et 20 pour cent respectivement. La valeur de l'index de thyroxine libre dans le sang a augmenté de 62 pour cent durant cette même période. La chirurgie ellemême a davantage augmenté ses paramètres. Ces données semblent indiquer que l'anesthésie à l'isoflurane et la chirurgie de la thyroïde augmentent le taux de thyroxine circulante chez l'homme.

\section{REFERENCES}

1. Oyama, T., Shmata, S., \& Matsukt, A. Thyroxine distribution during ether and thiopental anesthesia in man. Anesth. Analg. 48: 1-6 (1969).

2. Oyama, T., Shibata, S., \& Matsuki, A. Serum endogenous thyroxine levels in man during anesthesia and surgery. Br. J. Anaesth 4I: 103-108 (1969).

3. Orama, T., Shibata, S., \& Matsuxi, A. Thyroxine distribution during halothane anesthesia in man. Anesth. Analg. 48: 715-719 (1969).

4. Oxama, T., Matsuki, A., \& Kudo, T. Serum levels of thyroxine in man during spinal anesthesia and surgery. Anesth. Analg. 50: 309-313 (1971).

5. Oyama, T., Matsuki, A., \& Kudo, T. Effect of halothane and methoxyflurane anesthesia and surgery on plasma thyroid-stimulating hormone levels in man. Anaesthesia 27: 2-8 (1972).

6. General product information. Trilute ( $I^{125}$ column $T_{3}$ test), Tetralute ( $I^{125}$ column $T_{3}$ test). Ames Company, Elkhart, Indiana.

7. Abreau, C., Vagenakis, A., Azizi, F., Pontany, G., \& Braverman, L. A single method for measuring total thyroxine and free thyroxine index in serum. J. Nucl. Med. 14: 740742 ( 1973).

8. Gordon, A., Kreinerman, H., Ehrenfeld, M., \& Ehrenfeld, E. Parameters of serum binding of thyroxine in hypo-, hyper- and euthyroidism and their application to the control of therapy. Isr. J. Med. Sci. 7: 1029-1934 (1971).

${ }^{\circ}$ Forane is a registered trademark of Airco, Inc., Ohio Medical Products Division. 